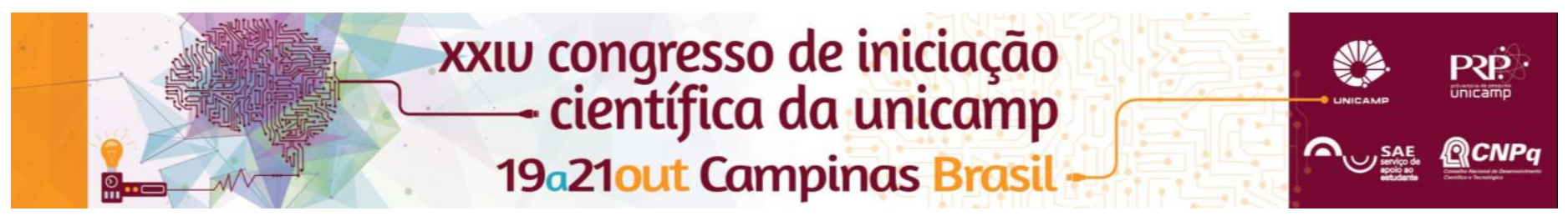

\title{
Internacionalização produtiva e tecnológica das grandes corporações: Análise da indústria automotiva
}

\section{Humberto M. M. Junior*}

\section{Resumo}

Este trabalho tem como objetivo analisar a distribuição geográfica das cadeias produtivas e das estruturas de pesquisa e desenvolvimento das grandes corporações pertencentes a indústria automobilística. Para isso foram verificados vários fatores que somam na tomada de decisão destas empresas, entre eles, a estrutura de mercado e de concorrência, os principais players do mundo, os principais países fabricantes e os principais países consumidores e as tendências tecnológicas.

\section{Palavras-chave:}

Pesquisa e desenvolvimento, indústria automobilística, cadeia produtiva.

\section{Introdução}

A indústria automotiva ao longo da sua história vem desempenhado um papel de grande relevância nas estratégias econômicas dos países possuidores desse setor produtivo. Desta forma, é imprescindível estudar as táticas corporativas de como são distribuídas as etapas da cadeia produtiva em torno do globo.

\section{Resultados e Discussão}

A indústria automobilística global é um setor chave para a maioria das economias nacionais, além de possuir uma grande importância no cenário industrial mundial. Entre os anos de 2004 e 2014 a produção mundial de veículos apresentou em sua totalidade crescimentos durante todo o período, com exceção dos anos de crise financeira mundial (2008-2009). ${ }^{1}$

A concentração dos principais grupos é um fenômeno característico do novo ciclo de acumulação mundial desencadeado a partir dos anos 70 e que ganhou maior força no fim dos anos 90. Até a união da Daimler-Chrysler (realizado em 1998, mas desfeito em 2007) e a aliança entre a Renault e Nissan (em 1999), a concentração global do segmento de automóveis da indústria automobilística havia passado por cerca de dez anos (1987 a 1996) de relativa estabilidade.

A participação de mercado dos dez maiores produtores superou $70 \%$ e dos vinte maiores quase atingiu $90 \%$ em 2014, refletindo o elevado grau de concentração econômica. Cabe destacar o movimento mais acentua do de incremento das atividades produtivas por montadoras asiáticas, particularmente a consolidação como players globais de fabricantes japoneses e sul-coreanos. A China tornou-se o maior demandante de veículos, ultrapassando os Estados Unidos em 2009. De fato a China absorveu $26,6 \%$ de toda a oferta mundial de veículos em 2014, o que é mais que a soma dos mercados dos EUA, Japão e Brasil juntos, respectivamente segundo, terceiro e quarto mercados globais. ${ }^{2}$

Para efeito da comparação e delimitação do espeço amostral estudado foram pegos os cinco maiores grupos produtores de veículos segundo a OICA no ano de 2014, Toyota, Volkswagen, General Motors, Hyundai e Ford (ver tabela 1) com a intenção de analisar os padrões de investimento e suas estratégias coorporativas.

Os gastos com P\&D das cinco grandes (Toyota, Volkswagen, GM, Hyundai e Ford) passou de 23,5 bilhões de euros (2010), com média de 4,6 bilhões de euros por empresa, para o montante de 33,2 bilhões de euros (2014), com média de 6,6 bilhões pode empresa. Isso corresponde a um aumento de aproximadamente $42 \%$ em relação a este período, algo maior que o crescimento do setor automotivo, que foi de $36 \%$ no período e do gasto total das 1400 maiores empresas, que cresceu $26 \%{ }^{3}$

Tabela 1. - Cinco Maiores grupos Produtores de Veículos em 2014

\begin{tabular}{|c|c|c|c|}
\hline & Grupo & $\begin{array}{l}\text { Total } \\
\text { produzido }\end{array}$ & $\begin{array}{l}\text { Market- } \\
\text { Share }\end{array}$ \\
\hline & Mundo & 90.717 .246 & $100,00 \%$ \\
\hline $1^{\circ}$ & Toyota & 10.475 .338 & $11,55 \%$ \\
\hline $2^{\circ}$ & Volkswagen & 9.894 .891 & $10,91 \%$ \\
\hline $3^{\circ}$ & $\begin{array}{l}\text { General } \\
\text { Motors }\end{array}$ & 9.609 .326 & $10,59 \%$ \\
\hline $4^{\circ}$ & Hyundai & 8.008 .907 & $8,83 \%$ \\
\hline $5^{\circ}$ & Ford & 5.969 .451 & $6,58 \%$ \\
\hline
\end{tabular}

Fonte: Elaboração Própria. Dados OICA

\section{Conclusões}

O setor de pesquisa e desenvolvimento dos grupos automotivo foca de maneira majoritária seu esforço nos países sedes da corporação, fazendo destas nações grandes focos de acumulação de conhecimento e atração de diversos outros centros de pesquisas.

Desta forma, fica evidente que a dinâmica atual dessas grandes corporações é de investimento que atraem investimentos, isto é, nações com grande massa de investimento em P\&D internas, feitas por indústrias nacionais, acabam atraindo outras empresas concorrentes para dentro do mercado interno de pesquisa e desenvolvimento.

\section{Agradecimentos}

O projeto só foi concluído pela oportunidade concedida através do PIBIC e pela orientação do Prof. Dr. Célio Hiratuka.

${ }^{1}$ PORTER, M.E. Competition in Global Industries. Boston: Harvard Business School Press, 1986

${ }^{2}$ SARTI, F. e BORGHI, R.A.Z. Evolução e desafios da indústria automotiva no Brasil: contribuição e debate. Friedrich Ebert Stiftung Brasil, 2015.

${ }^{3}$ http://iri.jrc.ec.europa.eu/scoreboard.html, acessado em 01/03/2016 